ern environmentalism may well be creating genuine social and political change.

After the United Nations Conference on Environment and Development in Rio de Janeiro earlier this year, it is evident that neither democracy as we currently know it, nor international diplomacy as presently practised, is ready for the constellation of adjustments that will be needed to form the simple but ungraspable trio of ecological health, social justice and guided enterprise on a degrading world stage. The problem for Lewis is that he devotes most of his effort to knocking down the straw people he has comfortably but misleadingly created for himself, and said too little about how to shift to a sustainable future based on the structures that plague us today.

In the area Lewis calls guided capitalism, there is a slim chance of progress. The major multinational companies have the capability and power to set an agenda for more-sustainable capitalism on a global scale. It would require a heroic shift in pricing, self-regulation, openness and management, and it would mean greater cooperation in terms of promoting broad principles and codes of practice than anything yet envisaged. But it is in this arena of international guidance and multinational support that the beginnings of a transformation could take place. Success would depend, however, on interventionist and radically equalizing parties at the head of government, and a citizenry that treated sharing seriously. There is absolutely no evidence that such ingredients are in place. The best one can hope for is a public debate around the preparation of national plans towards sustainable development that should emerge out of the Rio process. How far it will do so remains to be seen, and for now one must be very pessimistic. But as the world grinds into greater calamity and as each fresh generation takes the triple alliance of ecological health, social justice and guided enterprise more seriously, out of many ashes some form of modified phoenix, not Prometheus, could still arise. But it would be a leaner and much more devastated humanity that would have to adopt the mantle.

Timothy O'Riordan is at the School of Environmental Sciences, University of East Anglia, Norwich NR4 7TJ, UK.

\section{Environmental dictionaries}

Dictionary of Environmental Science and Technology (revised edition) by A. Porteous. Wiley, £9.95 (pbk)

- Dictionary of Global Climate Change compiled by W. J. Maunder under the auspices of The

Stockholm Environment Institute. UCL Press, £19.95 - The Earth Report 3: An A-Z Guide to Environmental Issues edited by E. Goldsmith and N. Hildyard. Mitchell Beazley, £9.99 (pbk).

\section{Humble homily}

\author{
N. A. Mitchison
}

Pietà. By George Klein. MIT Press: 1992. Pp. 297. \$24.95, £22.50.

GEORGE Klein will be well known to many biologists for his lifetime of research on cancer viruses as the founding director of the Department of Tumour Biology at the Karolinska Institute in Stockholm. His insight, pertinacity and imagination led him to create out of this specialized theme a structure of ideas that has deeply influenced contemporary immunology and developmental biology. The same qualities illuminate this, his second collection of memoirs and reflections (another is on the way).

Excluded from the executive arms of the state, the Jews of middle Europe gravitated towards intellectual pursuits. Their way of life was profoundly German in its orientation, and its destruction in the Holocaust is one of the ironies of history. Klein's upbringing in pre-war Budapest left him familiar with the main European languages, and with a love for the poetry of Rilke, Goethe, Baudelaire and (more curiously) Poe combined with respect for the ideas of Schopenhauer, Freud and the young Heidegger. He recounts the walks through the old city, the picnics on the island at its centre, the concerts and the fervid cafe discussions.

In 1944, at the age of 19, Klein escaped from the death train taking him from the city; many of his family perished. This book does not belong to the literature of the Holocaust, but its view of human nature is deeply influenced by that experience. It lets him sympathize with the poet Attila József, who dissociated himself from the bourgeois life of inter-war Hungary and who was condemned by others as schizophrenic. It underlines for him the desperate difficulty in the AIDS epidemic of changing human behaviour, especially in anything so basic as sexual practice. It prevents any surprise that the Central Intelligence Agency in the McCarthy era carried out experiments with LSD on volunteers.

Klein's main theme concerns the different ways in which individuals confront their own suffering and alienation. In some this generates creativity, a connection that is explored in some depth here, particularly in the instances of József and Nietzsche. The argument is of course not unfamiliar, and no doubt it needs the leisurely pace and breadth of an Edmund Wilson to do it proper justice; but the author's personal experience gives this account a special poignancy. The final chapter, from which this collection takes its title (loosely translated as 'compassion'), rounds up the argument and places it in the context of German philosophical writing.

Appreciating creativity in literature requires a knowledge of the language, a forlorn hope for most of us when that is Hungarian. Klein does his best, for instance in discussing József's provocative choice of a verb translatable as 'applaud' to describe what jasmine petals do. $\mathrm{He}$ succeeds within the limited space that he permits himself, and I hope will expand this line of thought in his next collection.

Klein tells a good anecdote. We learn in detail about an afternoon's conversation between François Jacob, Bruno Müller-Hill, himself and the now Canadian neuropharmacologist Rudolf Vrba. Vrba had participated in the first escape from Auschwitz, and had jointly written a report on conditions there that did much to save lives among the Jews of Budapest. These men's argument about the duty of the scientist, and the question of whether science itself has an internal ethic, will interest any reader of Nature. Klein is not at all egocentric, and in fact rather amusing about himself: totally confounding the officialdom of the airline Swissair, ferreting out the personalities that interest him, and defeating the efforts of his fellow citizens in Stockholm to engage him in chit-chat.

This collection also includes a little science. The brief histories of $\mathrm{T}$-cell biology and of the AIDS epidemic will interest nonspecialists, but Klein's very lack of egocentricity leaves one unsatisfied. I would have liked more about how he felt at the time and what impression the rest of the community made on him.

One of the things that Klein is best known for is the tape recorder that invariably accompanies him on his aeroplane flights. Well, anyone who wishes to emulate him in that respect should leave this volume behind: once started, it is impossible to put down. More generally, no science library that aspires to more than the narrowest interpretation of its function can afford not to purchase this volume to place alongside its Jacob, its Müller-Hill and its Medawars. And a final note to the professionals: the European Community plans next year to make awards in the field of medical ethics, in the hope no doubt of catching up with Golub's Pacific Center for Ethics and Applied Biology. This volume, and its predecessor The Atheist and the Holy City (MIT Press, 1990), in my opinion make ideal background reading for those thinking of submitting applications (the closing date for which is January 1993).

N. A. Mitchison is in the Deutsches Rheuma Forschungszentrum, Robert Koch Institute, Nordufer 20, 0-1000 Berlin 39, Germany. 